\title{
Significant factors of violence against women in urban and rural community
}

\author{
Marketa Rusnakova ${ }^{1}$ and L'udmila Huskova ${ }^{2}$ \\ ${ }^{1}$ Catholic University in Ružomberok, Ružomberok, Slovakia \\ ${ }^{2}$ Police of Slovak Republic, Martin, Slovakia
}

\begin{abstract}
Introduction. The research is focused on the issue of domestic violence against women. It deals with the definition of violence, concepts and models of individual areas by summarising the research findings and the possibilities of methodological tools for measurement of significant factors of violence against women. Aim. The primary goal of the research is to define significant factors which determine violence against women. Material and Methods. Methods of research - survey, document analysis and database statistical analysis. Results. Primary results of quantitative research reveal that women of all ages and educational groups are at risk. Mostly women aged 26-45, living in rural areas with middle school education without maturity exam (final exam). Violence in families involves men of all age groups with emphasis on increased incidence in specific categories: mostly men aged 36-45, living in rural areas with secondary (high school or comprehensive school) education. Another field of interest represents analysis of negative family situations, impact of violence against woman on her psychological conditions, and reasons why victims carry on marriage and/or partnership. Conclusions. It can be concluded that the most frequent negative phenomena during aggressor's and/or victim's childhood were physical violence of father against mother, alcohol - possibly father's alcoholism, poverty, physical punishment of children, and patriarchal model of the family. Two thirds of victims continue marriage/partnership in order to maintain the family, to keep the father for children, and for financial reasons. There is a frequent social criminality in poor biological families of aggressors, i.e., a commission of crime because of lack of finances.
\end{abstract}

Key words: significant factors, violence against women, mistreatment, victim, aggressor.

\section{An overview of research activities focused on violence committed against women in the Slovak Republic}

In the past research works conducted in the field of violence committed against women were solved on the agenda with the variable intensity. In our view, the present topic is currently being addressed more intensively by both governmental and non-governmental institutions. The history of domestic violence research or research of violence committed against women in the Slovak Republic (SR) is much shorter than history in western democracies, where the similar researches have been conducted since the late sixties of the 20th century. Initially, just partial explorations were realized in the Slovak Republic, which were only tangentially related with the issues, or there was some unrepresentative probe. We have chosen from the research activities in SR in nineties of the 20th century: The exploration of Democratic Union of Women of Slovakia "An analysis of intolerance towards women" (1994), The survey of the 
International Centre for Family Studies (ICFS) "Family 1995" (1995), The Exploration of ICFS "Women about themselves" (1997), The state of violence committed against women in SR, The exploration Pro Families and the Centres of Counselling and Psychological Services "Beaten women in Slovakia" (1997), The Exploration of The International Organization for Migration (IOM) "The trafficking of women in SR" (2000) [1].

A good example of this is regular empirical sociological research of the Institute for Public Affairs in the years 1995, 2000, 2002 and the exploration of the group of women nongovernmental organisations (MVO) in the year 2001 within the campaign "The fifth woman". The first press monitoring was realized in 1999 within the project Ester Mirror which was supported by Canada Fund in SR. The monitoring was prepared by interest association of women Fenestra with its registered office in Košice [1].

In the years 2001-2002, the International Centre for Family Studies widely tried to process information about the domestic violence cases that were in records of the Centres of Counselling and Psychological Services in SR financially supported by Friedrich Ebert Foundation, representation in SR. The research was based on clinical sample of advisory centres' clients (both men and women) who were aware of being violence victims [2]. During the period of Czechoslovak Socialist Republic and the period of federal government as well as the first 12 years of independent Slovak Republic, the issue about violence committed against women within the country was not specially researched and monitored from the legal perspective.

The first systematic research under the patronage of General Prosecutors Office of the Slovak Republic has been "The Evaluation of using criminal law means against the domestic violence towards women and children" ("The Evaluation") published on 30 June 2002 (General Prosecutors Office of the Slovak Republic, online). The Evaluation has proceeded from the statistical data of the all regional prosecutor's offices in the district of General Prosecutors Office of SR in the years 1999-2001. For example, the prosecution started for 1.614 acts of domestic violence against women in the year 2001, which is a rise of $5.6 \%$ than in 2001 and $14.3 \%$ more than in 1999. Apart from the quantitative research, the results have been subsequently evaluated with the proposal of consequences for more effective elimination of this widespread form of violence [2].

Slovakia was one of the last countries where the representative research was carried out, although it has not been done from the state budget resources. The first representative research was conducted by women employees of the Centre for Work and Family Studies in 2002. The research was comprised of two main parts. The first part of the research under the title of "Domestic violence - experience and attitudes of inhabitants of SR" focused on occurrence of various forms of domestic violence in Slovakia, measuring the attitudes and tolerance of Slovak society to domestic violence as well as the level of willingness to intervene in similar situations [2]. The second part of the research under the title of "The violence committed against women - experience and attitudes of women in SR" focused on finding out the occurrence, frequency, extent and essence of the violence committed against women in SR [2]. After 2002, on the initiative of the National plan of action 2005-2008 the monitoring of the organizations which provide help for victims of domestic violence was realized (2006) and five years later the second "Representative research of the occurrence and women experience of violence committed against women (VAW) in Slovakia” [3]. The Department of Gender Equality was the contract owner securing finances too. It was conducted by the Institute for Labour and Family Research (ILFR). These are some of the main findings of the research:

- There is every fifth woman in Slovakia: every fifth adult woman, who currently has a partner, has experienced violent behaviour from his side - to be more precise $21.2 \%$ of adult women in Slovakia aged 18-64 years, who had a partner at the time of research, 
had experienced an act of violence from the partner (it was pronounced violence in $6 \%$ of the cases, it means often repeated physical and sexual violence and almost constantly present mental, social or economical violence).

- The incidence of the violent behaviour against women committed by former partners is even higher: of adult women who had a former partner, $27.9 \%$ had experienced an act of violence, of whom $12.2 \%$ had experienced pronounced violence.

- There is no type or form of violence against women in intimate relations that would be completely unknown to Slovak women: all known forms of violence have occurred - from the physical and sexual violence, through mental and social up to economical violence (physical violence has been experienced from the present partner by $15 \%$ of women and from the previous partner by almost $40 \%$ of women, $9 \%$ of women have had an experience with the sexual violence from the present partner and $25 \%$ of women have experienced the sexual violence from the previous partner).

- Women in Slovakia are rarely exposed to only one form of "partner's" violence: physical violence is very often preceded or accompanied by mental or social violence, sexual violence is very often connected with various forms of mental or social violence, economical violence is closely linked to mental violence etc.

- The relationships with the present violence against women are not random relationships: it is usually a bond of marriage (violent relationship $-76 \%$ of women who are in their first marriage, clearly defined violent relationship almost $80 \%$ of women in their first marriage) and a long-standing relationship (on average more than 20 years'standing).

- Children are often witnesses to violence: almost $70 \%$ of women who have experienced violence from their present partner live together with their children or a child.

- The violence in intimate relationships is experienced by women of all age groups and with increased occurrence in a particular group: the violence occurs among women of all age groups but it is more frequent among middle-aged women (45-60 years); the violence affects women with all levels of education, however, the biggest group is comprised by women with elementary education and with apprenticeship; economically active women, as well as economically inactive women live in the violent relationships, from the group of economically active women there are mainly manual women workers and skilled women workers, from economically inactive women the highest percentage of women are retired women; according to the size of residence there are mainly women living in the smallest municipalities up to 2000 inhabitants.

- All groups of men participate in the violent relationships, with an emphasis on higher occurrence in particular categories: all age groups of men commit violence in intimate relationships, but violence is more frequent among older men (45 years and more); violent men could be found in every educational category, however there is a higher rate of committing violence among men with elementary education and with an apprentice school education without school leaving examination; there are all groups of economically active men, however blue-collar workers dominate as well as men who are out of labour market" [3], p. 10-12.

"Monitoring of the media and advertising from the viewpoint of violence committed against women and gender equality support in 2011" dealt with chosen cases of media and marketing discourses from the point of view of women sexualization and objectification the mechanism of women devaluation and maintaining gender stereotypes [4]. The report has brought the results of the chosen media news monitoring. A standardized methodology enables to compare media coverage and the news relevance about the violence committed against women as well as reporting of gender presentation news in the years 2009-2011 [4]. The ILFR report has offered analysis of the chosen news content about the violence 
committed against women and it has revealed the mystifying and misleading signs of this issue presentation. The ILFR has realized Monitoring of the social services for women experiencing the violence and for their children from the viewpoint of European standards and it has shown the results of the chosen social services for abused women with the children [5]. The ILFR conducted researches within the national project The Support of the Prevention and Elimination of Violence against Women (ILFR, online). They were the following: Special groups of women in danger of violence - older women, Special groups of women in danger of violence - women from the rural environment, Special groups of women in danger of violence - women with an experience of being raped and the sexual violence experience [14].

The researches of violence against women provide current information about the occurrence and the character of violence against women. They have revealed new findings as well as those which confirm or deepen former ascertainment. The researches of different society areas subjects, an effort to improve legislative environment, the standardization of intervention procedures and media campaign have indicated, that violence committed against women is still present and urgent problem.

Taking the mentioned facts into consideration, it is our belief that, in the Slovak Republic it is necessary to conduct specialized research aimed at particular spheres, which are connected with violence against women factors. Our survey belonged to this category. The relevant researches are being mentioned in the chapter no. 1 of the dissertation. The results of the researches will be introduced in particular topics and the chapters about the research results and conclusions.

\section{The rural environment}

The violence affects a large number of women in various contexts, at any age, ethnic, religious or cultural backgrounds. There are only a few data about the extent and character of the violence that affects women in rural environment, older women or disabled women.

\subsection{Women from rural environment}

Regardless of numerous positive attributes associated with rural environment, the presence of violence against women is, in addition to various other forms of violence, indeed a serious problem. Due to structural changes in the economy of rural areas, there has been an increase in the share of population which is at risk of poverty or social exclusion. According to data of the Statistical Authority, it is women, as a matter of fact, who are at risk of poverty, in particular women over 65 and women who are unemployed [6]. On the basis of the selected indicators it is possible to get an idea about the social as well as economic situation of rural population. The connections among social and economic development, position of women and violence against women are becoming a topic also through policies and programmes for encouraging women in achieving full economic independence, which applies particularly to women living in rural areas. We believe that attitudes of the public to violence vary according to the region. Rural population seems to be more traditionally reasoning, more religious, more conservative and in this sense also more identifying itself with tabooing of violence against women. Arguments can be found in the representative survey of the occurrence and the experience of women with violence against women, conducted by the Institute for Labour and Family Research in 2008. A non-interfering and passive approach to addressing of violence 
between partners was found particularly in respondents with basic education, over the age of 60 , of other nationality, living in the small municipalities up to 2000 inhabitants and the widowed [3]. In order to correctly identify rural women, it is necessary to define the meaning of countryside or rural area. Sandberg (2013) draws attention to the problem of defining rural area, as it is locally very specific geographic characteristics. In general, rural environment can be defined as an area of low population density, but even this criterion has different value in different countries [7]. Even in Slovakia there are differences in the understanding of countryside. Buchta (2012) relies on the OECD definition which speaks about double method of defining a rural area. On a local level, a rural municipality is considered to be a municipality with population density of less than 150 inhabitants per $\mathrm{km}^{2}$ [6]. According to the Act on Municipal Establishment, a rural municipality is one with less than 5000 inhabitants. At the same time, however, the act draws attention to the fact that even in the case of number of inhabitants smaller than 5000, a municipality may be declared a city if it possesses corresponding services, transport connections as well as urban character of the built-up areas and, at the same time, it is an economic, administrative and cultural centre, a tourist centre or a spa location [12].

Our experience shows that violence against women has specific and mutually differing characteristics in the case of rural and urban environment. With regard to occurrence of violence, studies from abroad report different prevalence rates. Some of them speak of higher occurrence of violence in the cities, others, on the contrary, in the rural areas. There are also studies showing comparable occurrence of violence, however, there are factors which cause this similarity to remain hidden (e.g. Thurston, Patten, Lagendyk 2006; Peek-Asa 2011; Shuman 2008) [7-10]. Certain factors may be involved in the fact that cases of violence in the countryside are reported to a lesser extent than in the cities. The literature also refers to specific attributes of rural area which may promote violence against women as well as increase the probability of returning to the violent partner in cases of women trying to escape (e.g. Thurston, Patten, Lagendyk 2006) [8]. Another problem faced by women experiencing violence in rural areas is acceptance of violence as a part of life, or even its tolerance by the community. Obviously, this is not a flat-rate approach. However, due to the persisting traditional views and a higher degree of conservatism, influenced also by a different religious structure compared to the urban population, it is not rare that it is indeed rural women experiencing violence who do not find understanding [7]. Tabooing of violence is another problem that is more typical of rural localities and that accompanies a higher degree of conservatism and traditional understanding of gender roles. There may be a predominant belief that family problems should remain and should be dealt with in the close family circle and that it is not desirable that intimate issues be brought out and discussed outside of the family. However, one of the most significant problems of rural women experiencing violence is geographic isolation. Such isolation is accompanied by several adverse facts, such as, for example, poorly constructed or no network of social care facilities for women experiencing violence. The geographic unavailability of certain rural settlements also facilitates social isolation of women experiencing violence and easier hiding of violent behaviour [9]. Insufficient education is also connected to poor awareness of assistance services for women experiencing violence. According to the studies by foreign authors, a lot of women are not aware of the existence of shelters for abused women. When analysing rural environment in relation to the issue of violence against women, it is necessary to mention questions of unemployment or poverty and low living standard. Several foreign studies also prove that a poor social-economic situation is one of the factors in the case of women experiencing violence as well as in the case of offenders $[7,10]$. 


\section{Differentiations of abuse signs in the context of residence of abused women and aggressors}

During years 2014-2016 we conducted a survey aimed at identification of significant factors underlying violence against women in family environment. The survey sample consisted of the total of 184 respondents, 92 victims and 92 offenders committing a crime of abuse against a close person or a person entrusted in one's care. For the purposes of the conference we chose one survey question through which we tried to identify differentiating signs of abuse in abused women and aggressors from rural and urban environment. In this context we established one survey question: Are there any statistically significant differentiations in abused women and aggressors in relation to the place of residence? Is the ratio of abused women and aggressors different based on their residence compared to population distribution in the observed region? And three hypotheses:

- H1 We assume that among victims of abuse there are significantly more women from rural areas.

- H2 We assume that among aggressors there are significantly more men from rural areas.

- H3 We assume that among victims as well as aggressors there are significantly more respondents from rural areas compared to population distribution in the observed region.

For conducting of the survey, we chose the method of content analysis of documents, the document files of criminal offences of abuse against a close person or a person entrusted in one's care-section 208, which had female victims. Investigation files used in our survey are from Department of Criminal Police of the District Police Headquarters in Martin (hereinafter referred to as DPH). An investigation file can be defined as "all written documents related to the same investigated criminal case (submissions, reports, records, decisions, etc.), forming the investigation file that is opened after receipt of the first submission in the case" [11]. With respect to the objectives and the hypotheses of the submitted work survey, the relevant documents were the following:

- records from hearings of the victims, the accused and the witnesses, the court experts, motions to press charges,

- expert opinions from department of clinical psychology and psychiatry, medical reports,

- preliminary measures, criminal orders, resolutions, verdicts and screening data.

Documents are maintained in the archives of the DPH, organized by the year of filing of a criminal complaint.

In the abused women documents we focused on the following areas of study:

- social - demographic characteristics of perpetrators of violence,

- factors influencing violence in relation to the victim and the aggressor,

- specific forms of violence, duration of violence, consequences to women's health,

- history of primary family environment of perpetrators of violence.

In order to achieve the main objective and the partial objectives, we used data obtained by analysis of the investigation files regarding abuse against a close person or a person entrusted in one's care. We presented the obtained data using descriptive statistics in the form of chart and spreadsheet presentation of data which includes numeric and percentage values. To test the significance of the differences found on the basis of information obtained from quantitative data, we used the Chi-square test (with Yates's correction at low values in the 
Table 1. Percentage distribution of the survey sample based on the place of residence.

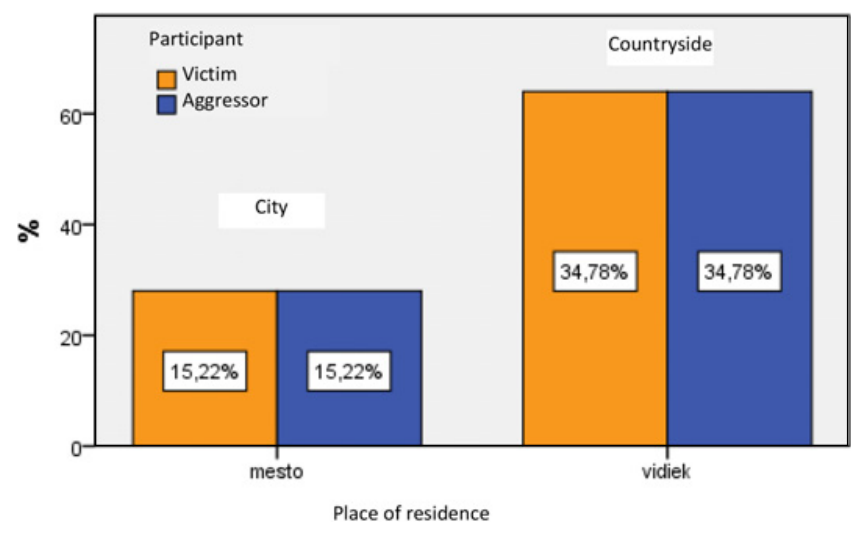

contingency table), Fisher's test, (GraphPad Instat), Shapiro-Wilk test for testing of normality of data distribution, Mann-Whitney U-test and Kruskal-Wallis test.

Table 1 shows the represented ratios of women from rural environment and from cities in our survey sample.

The hypotheses were verified by Chi-square statistical test for one choice. The test assumes that the occurrence of the observed phenomenon (residence) will be similar in each group. The results show that differences in the residence of abused women are statistically significant $(p<0.05)$.

The survey also shows that there is a statistically significant difference $(p<0.05)$ in the rate of sexual assault incidents with respect to the place of residence and the age. Victims from the cities face a higher rate of sexual assault incidents (1.21 on average) compared to victims from rural environment ( 0.61 on average). The average values also suggest that victims between 18 and 25 years of age face the highest rate of sexual assault incidents (1.53 on average) compared to victims between 26 to 35 years of age ( 0.82 years of age), between 26 and 45 years of age ( 0.70 on average) and victims over 46 years of age ( 0.08 on average). Sexual assault incidents therefore decrease proportionally with age.

Our hypotheses assumed that there are more rural respondents among victims and aggressors of abuse. This fact was confirmed, as the majority of victims as well as aggressors live in rural areas (64 victims and aggressors live in rural areas) $(p<005)$, despite the fact that in the towns of Martin, Turčianske Teplice and Vrútky almost 2/3 of population are adults. In comparison to population distribution in the observed region, the ratio of victims and aggressors from rural environment is significantly higher $(p<0.05)$. According to the survey by [3] women of all categories experience violence in intimate relationships, while the occurrence is higher in a specific category: with respect to the size of the residence area, these are particularly women from municipalities with population under 2,000. In the context of studying violence against women, an important attribute is locality, which is conditioned geographically and culturally. The question that remains is how much the locality, or a dichotomous relationship between the countryside and the city, represents an important attribute in identifying of abused women particularities. Studying of the relationship between countryside and gender requires detailed focus on the experience of women and men who live in this environment. In the effort to adequately capture this experience, the affiliation to the countryside represents only one category in the entire complex of mutually overlapping categories. Sandberg points out that the existing studies and theories, even in the intersectional context, do not look at the issue of violence against 
women in the context of geography and locality. He claims that "differences that exist between urban and rural regions in relation to specific conditions and problems faced by persons experiencing violence in intimate relationships are being overlooked" [7]. And yet the rural environment itself can often become the target of disadvantageous attitudes and believes. Cultural "representations" attribute typical values and dominant meanings to the countryside. It is usually associated with purity, harmony, safety or solidarity, simply put, the qualities which are lacked by the city or the urban environment. On the other hand, the countryside is also represented as reactionary, traditionalist and conservative (Bryant, Pini 2011). In relation to women experiencing violence, the strengthening of certain attributes might translate into these women's marginalisation, discrimination and victimisation. Localities, as geographic and cultural categories, are part of power relationships and therefore relationships which promote either exclusion or inclusion of individuals and groups, including women.

\section{Summary}

Socio-demographic factors as a place of living, economic inactivity, poor education, family and marital status, alcohol, social pathology in a biological family of the perpetrators as well as personality disorders can result in the formation, persistence and intensity of violence committed against women. We have formulated the research problem, the aims, survey questions and the hypotheses of the empirical part. The primary aim of the empirical part was to identify significant factors conditioning the violence against women in family environment. In order to achieve the main objective, it was used the method of content analysis of documents, the document files of criminal offences of abuse against a close person or a person entrusted in one's care - section 208, which had female victims. On the basis of the survey it could be stated that: abused women experience violent relations with repeated signs of mental, physical, social and economic violence with lower occurrence of sexual violence. All age groups of women and women with all levels of education are in danger of violence, the most often there are women aged 26-45 years who live in the countryside with elementary education or high school education without school leaving examination, married. All groups of men participate in violence in a family environment with an emphasis on higher incidence in particular categories: the most often there are men at the age of 36 to 45 years, living in rural areas, with high school education (without school leaving exam, with school leaving exam). The second researched area was the analysis of unfavourable situations in family, the impact of the violence on the woman psyche and the reasons for remaining in a bond of partnership. It could be pronounced that the most frequent negative phenomenon in both aggressors and victim's childhood was physical violence of father against mother, an alcohol problem of a father, poverty in a family, physical punishment on children and patriarchal behaviour of a father. Two thirds of victims remained in a violent relation for these reasons: an effort to preserve the family because of children and the fear of losing financial security. Social criminality, it means committing crimes as a consequence of want of money, often occurred in poor biological families of perpetrators.

It is necessary for social work as a science to search for ways of problem solutions of violence committed against women in family environment, but it requires sufficient knowledge of the problem to have at disposal. It is evident that tabooing of violence committed against women is still considerable because of the fact, that violence in a family is hidden matter. Therefore, it was necessary to aim the dissertation at problems of significant factors of violence, specifically abused women in a family environment, which were investigated in DPH in Martin. We had an approach to 92 investigation files of victims of neglecting and abuse against a close person and a person entrusted in one's care. We are of the opinion that social work can benefit from the topic of women abuse, criminal proceedings 
system, the importance of expert opinions, and determination of the factors from the victim's side as well as perpetrator. Reporting and record-keeping data could be a significant source of information for social worker's needs. We can apply research showing information to identify violence more accurately, to estimate danger and to work with an abused women and aggressor. Obtained information could be useful to make practical steps to the help and prevention of the violence against women more efficient.

\section{References}

[1] Z. Bútorová, J. Filadelfiová, Násilie páchané na ženách ako problém verejnej politiky, (2005). Available at: http://www.ivo.sk/479/sk/vyskum/nasilie-pachanena-zenach-ako-problem-verejnej-politiky

[2] B. Bodnárová, J. Filadelfiová, Domáce násilie na Slovensku. Priebežná správa 2/2002, (2002). Available at: www. ceit.sk

[3] B. Bodnárová, J. Filadelfiová, B. Holubová, Reprezentatívny výskum výskytu a skúsenosti žien s násilím páchanom na ženách. Záverečná správa Vú č.2224 (2008). Available at: www.ceit.sk

[4] B. Holubová, Monitoring médií a reklamy z hadiska násilia páchaného na ženách a podpory rodovej rovnosti za rok 2011 (2011). Available at: www . ivpr.gov.sk

[5] B. Holubová, J. Filadelfiová, Monitoring sociálnych služieb pre ženy zažívajúce násilie a ich deti z hadiska európskych štandardov (2013). Available at: www. genderdatabaza. wordpress. com

[6] S. Buchta, Možnosti a perspektívy riešenia vidieckej zamestnanosti. Sociológia 39(2), 119-135 (2007)

[7] L. Sandberg, Backward, Dumb, and Violent Hillbillies? Rural Geographies and Intersectional Studies on Intimate Partner Violence. J. Women and Soc. Work 28(4), 350-365 (2013)

[8] W.E. Thurston, S. Patten, L.E. Lagendyk, Prevalence of Violence Against Women Reported in a Rural Health Region. Can. J. Rural Med. 11(4), 259-267 (2006)

[9] C. Peek-Asa et al., Rural Disparity in Domestic Violence Prevalence and Access to Resources. J. Women's Health 20(11), 1743-1749 (2011)

[10] R.D. Shuman, jr., Understanding Intimate Partner Violence Against Women in the Rural South. Violence and Victims 23(3), 390-405 (2008)

[11] Decree no. 618/2005 Coll. of the Ministry of Interior of the Slovak Republic on compiling of files by law enforcement authorities and courts

[12] Act on Municipal Establishment no. 369/1990 Coll., section 22, paragraph 1

[13] L. Bryant, \& B. Pini, Gender and Rurality (Routledge, New York, 2011) (9-7804-15488990)

[14] Inštitút pre výskum práce a rodiny (IVPR, ILFR). Podpora prevencie a eliminácie násilia na ženách. Bratislava: IVPR (2015). Available at: <www . ivpr .gov .sk> 